Bangladesh J. Sci. Res. 27(1): 75-86, 2014 (June)

\title{
ASSESSING RISK OF CLOGGING IN COMMUNITY SCALE MANAGED AQUIFER RECHARGE SITES FOR DRINKING WATER IN THE COASTAL PLAIN OF SOUTH-WEST BANGLADESH
}

\author{
Sarmin Sultana* and Kazi Matin Ahmed \\ Department of Geology, University of Dhaka, Dhaka-1000, Bangladesh
}

\begin{abstract}
Community scale managed aquifer recharge (MAR) has been implemented by infiltrating pond and rooftop rainwater into shallow, locally confined brackish aquifers in the southern deltaic plains of Bangladesh for providing safe drinking water. This paper mainly deals with the risks of physical clogging and the issues of clogging related to aquifer material, design, drilling and construction methods at 20 sites. Risk of chemical and biochemical clogging has also been briefly discussed. High turbidity in the source pond water is mainly responsible for physical clogging. In order to reduce the turbidity MAR system has been designed with an over ground double chambered filtration tank with a graded sand filter in one chamber. Pond water is pumped into the filtration tank to pass through sand filter. Efficiency of turbidity removal is assessed by measuring turbidity of water at the source pond, after passing though the sand filter and at the abstraction well. The turbidity of source (pond) water ranges from 50 to 150 NTU decreases to 5 NTU after passing through the sand filter in most of the sites. Clogging is assessed by performing falling head tests at each recharge well at number of times during the operation of the test sites. A maximum infiltration rate of $6 \mathrm{~m}^{3} /$ day has been achieved at a number of sites where the average is about $3 \mathrm{~m}^{3} /$ day. Relatively high nutrient content present both in source and groundwater water could cause biological clogging. Probability of clogging due to clay swelling should be considered due to salinity difference of source and groundwater although sodium adsorption ratio has been observed to be reduced which reduce the risk of reduction of permeability. There is possibility of chemical plugging in the aquifer and around the well from the precipitation of iron bearing minerals as iron concentration has been observed to be reduced.
\end{abstract}

Key words: Managed aquifer recharge, physical clogging, turbidity, biological clogging

\section{Introduction}

Managed aquifer recharge (MAR) is increasingly being considered as a good option for water supply as it provides large storage capacity to capture intermittently available excess seasonal water for using it during scarce period. An action research on application of MAR with options to store pond water and rainwater into shallow, brackish aquifers in

\footnotetext{
"Corresponding author: <sarmin@du.ac.bd>.
} 
20 sites on the coastal plains of Bangladesh through recharge well under gravity has demonstrated the feasibility of freshening the salty ambient groundwater. This method can support community level potable water supplies in those acutely fresh water scarce rural areas. Fig. 1 shows a complete MAR scheme at Batiaghata in Khulna. The sites have been tested during the monsoon of 2012 by monitoring quality of pond water, filtered water and groundwater together with system performance by recording infiltration and abstraction volumes. Parameters such as EC, turbidity, $\mathrm{pH}$, temperature, water level, arsenic and iron are measured in the field at a number of objectively designed monitoring wells using portable meters on daily or weekly basis.

Although MAR is a proven technology, sometimes after successful construction, their performance may not meet expectations or have failed entirely due to lack of proper management during operation. The reduction in hydraulic conductivity around recharge wells is still a frequent reason for abandonment of MAR schemes. Clogging is a more significant issue for recharge well and can occur in the well screen, filter pack or aquifer
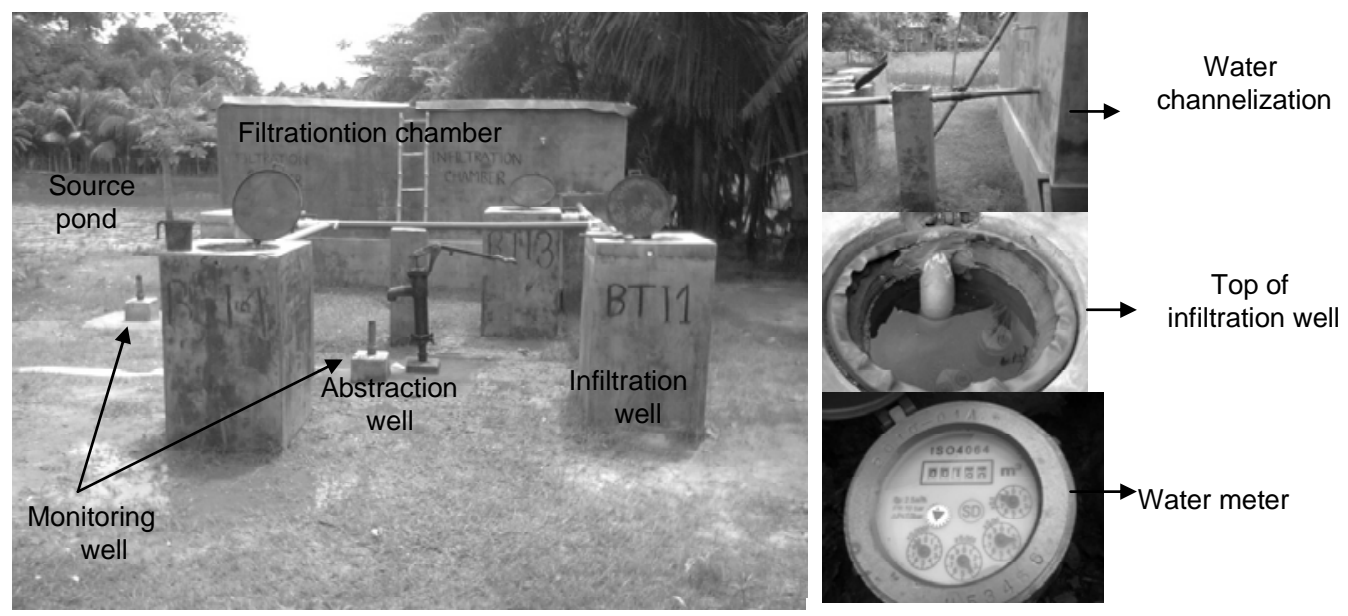

Fig. 1. A complete managed aquifer recharge scheme at Batiaghata, Khulna.

and can have a physical, chemical or biological origin. This paper deals with the risks of physical clogging specifically focusing on control of clogging due to turbidity in source water by filtration. Clogging issues related to aquifer material, design, drilling and construction methods have also been reported. Risk of chemical and biochemical clogging has also been very briefly discussed in the form of expected mineralogical change due to mixing of source and ambient groundwater and their interaction with minerals present in aquifer sediment. 


\section{Host aquifer characteristics}

The storage zone in the target area is shallow brackish aquifer, composed of unconsolidated fine to medium grained sand, occasionally interbedded with silty clay with a static water level from 1 to $2.5 \mathrm{~m}$ below the ground surface. Quartz is the predominant mineral in the aquifer sand with feldspar and mica and variable quantities of clay minerals with occasional un-decomposed wood fragments. Hydraulic conductivity in the aquifer sand is in the range of 10 to $20 \mathrm{~m} / \mathrm{d}$, overlain by clay aquitard of varying thickness. Both the texture and mineralogical composition of the aquifer lead to design and operational challenges. In general the risk of clogging depends upon the pore size distribution within the aquifer particularly if composed of fine grained material (Maliva and Missimer 2010). However, fine to medium grained sand aquifers are prone to clogging caused by presence of suspended solids in the injected water.

\section{Source water and ambient groundwater quality}

The turbidity of source pond water in the current study ranges from 50 to 150 NTU except at one site. Higher values of turbidity in source pond water have been observed at the advent of monsoon and lower values were recorded during the peak monsoon. Table 1 lists various physical and water quality parameters of pond water and ambient groundwater.

Table 1. Various physical and water quality parameters for pond water and ambient groundwater.

\begin{tabular}{cccccccc}
\hline $\begin{array}{c}\text { Parameter } \\
\text { unit }\end{array}$ & $\begin{array}{c}\text { Turbidity } \\
\mathrm{NTU}\end{array}$ & $\mathrm{pH}$ & $\mathrm{EC}$ & $\mathrm{PO}_{4}$ & $\begin{array}{c}\mathrm{SO}_{4} \\
\mathrm{mS} / \mathrm{cm}\end{array}$ & $\begin{array}{c}\text { Tempera- } \\
\text { ture } \\
\left({ }^{0} \mathrm{C}\right)\end{array}$ & $\begin{array}{c}\text { Total } \\
\text { coliform } \\
\text { cfu/100 ml }\end{array}$ \\
\hline $\begin{array}{c}\text { Pond water } \\
\text { (source) }\end{array}$ & $50-150$ & $7.5-8.5$ & $0.3-1.5$ & $0.2-1.5$ & $4.5-330$ & $28-36$ & $80-100$ \\
$\begin{array}{c}\text { Ambient } \\
\text { groundwater }\end{array}$ & $5-10$ & $6.5-7.5$ & $4-6$ & $0.1-9.5$ & $3.5-108$ & $27-30$ & $0-5$ \\
\hline
\end{tabular}

Gas binding may be a cause of clogging in the present study as there is a significant temperature difference between the injected water and ambient groundwater (Maliva and Missimer 2010).

\section{Pretreatment of source water}

Pretreatment is needed as source water contains suspended solids, organic matter, pathogens and other compounds that would result in rapid well or aquifer clogging during injection. A double chambered filtration tank has been constructed, placed on the ground or elevated up to $3 \mathrm{~m}$ above the ground, with a sand filter in one chamber. Pond water is 
pumped into the filtration tank to pass through sand filter. A screen is attached to the intake of pump to prevent rotten leaves, fish and other coarse debris from entering the filtration system. The sand filter is composed of different sized sand coarser at the bottom and finer at the top. The coarse sand is locally known as Sylhet Sands with diameters ranging from $0.5 \mathrm{~mm}$ to $2 \mathrm{~mm}$; the finer fraction has a diameter of less than $0.5 \mathrm{~mm}$. In this filtration system water slowly percolates downward, resulting in the removal of turbidity and pathogens through physical processes. There is no chemical treatment involved in this process.

\section{Well design}

The filtered water is regulated to the large diameter recharge wells through a pipe network fitted with stop valve and flow meter to pass through the injection well to reach the aquifer under gravity. Appropriate design of well is required for the life of system as inappropriately designed wells may clog within a matter of weeks. The recharge wells have been designed innovatively which employs a second stage of filtration of the filtered source water. Four recharge wells of 22 inches diameter have been drilled at each site to a depth of 60 to $100 \mathrm{ft}$ using locally available materials and drillers. Direct circulation rotary and reverse circulation percussion drilling methods have been used using water based drilling mud with clay and cow-dung as additives. This clay drilling mud may have significant impact on reducing well hydraulic conductivity of the aquifer material. Screen has been placed at the bottom of the casing in the sandy layers that have been innovatively designed using low cost mild steel rod frame wrapped with chicken mesh with $1 \mathrm{~mm}$ slot opening. The recharge wells are filled with sorted gravel of $>2 \mathrm{~mm}$ diameter with thin layer of fine sand $(30 \mathrm{~cm})$ at the top. Local aquifer sands have been used to fill the annular space at least one foot above the screened zone. Finally a clay sealing has been used to prevent percolation of untreated water through the annular space (Fig. 2). Two monitoring wells are installed inside the recharge well screened at the top and bottom of the well to monitor turbidity and other chemical parameters as well as to use it for backwashing. An array of monitoring wells has been placed outside the recharge wells at $1 \mathrm{~m}$ radius of recharge wells. Backwashing has been carried out immediately after the well construction and prior to injection to remove finer materials present in the hole. The abstraction well has been placed at the centre of the infiltration system and screened at the middle of the target aquifer. In the injection well after passing through the thin fine sand layer water flows through high permeability layer of sorted gravel and reach the aquifer which is again a low permeability layer. Thus it creates hydraulic barrier which somehow reduce infiltration rate. 


\section{Well performance}

Falling head tests have been conducted to measure the optimum rate of infiltration at each recharge well immediately after the completion of construction in order to get maximum rate of infiltration that can be achieved from an individual system. Individual well performance varies from site to site, even well to well within a site. Clogging of the
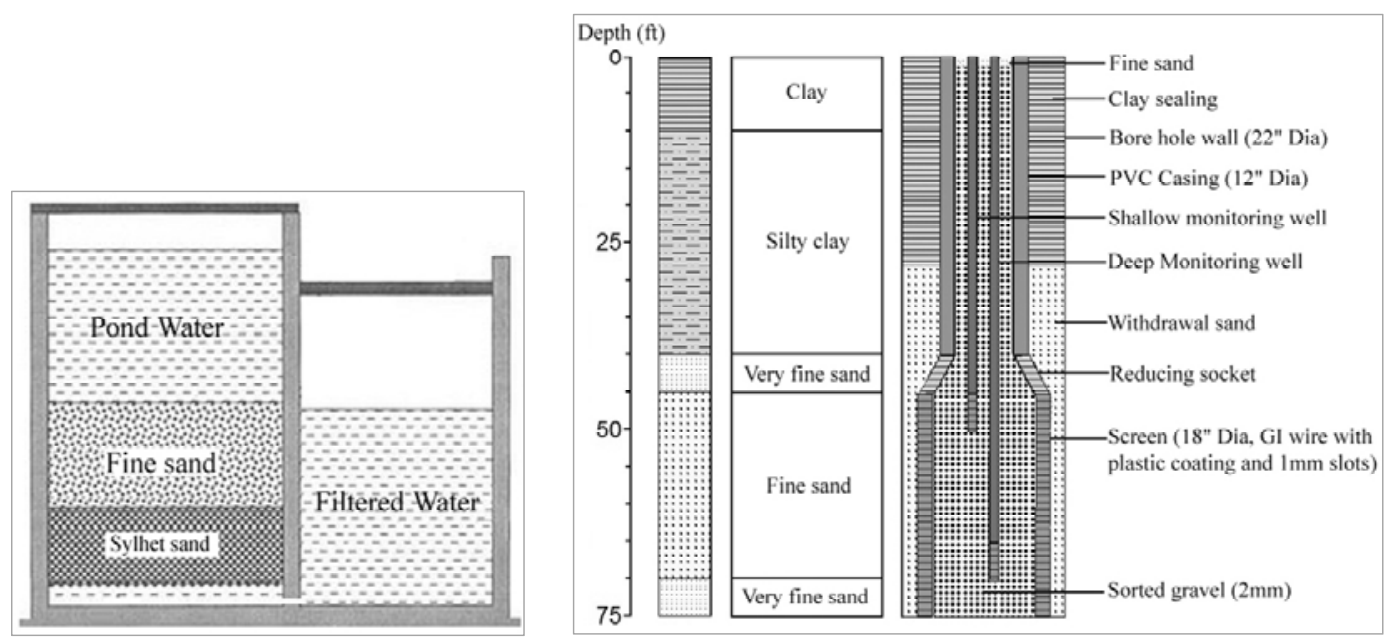

Fig. 2. Filter design (left) and well-construction diagram for MAR scheme (right).

system is monitored by continuously observing the infiltration rate during operation. Fig. 3 shows comparison of mean operational and optimum rate of infiltration in bar diagram with total amount of infiltration in line curve. Average operational infiltration rates vary from 1 to $6 \mathrm{~m}^{3} / \mathrm{d}$ and optimum infiltration rates vary from 2 to $20 \mathrm{~m}^{3} / \mathrm{d}$. There is a large separation between the mean operational rate and optimum rate and this is due to operation and maintenance and scarcity of source water during dry period apart from clogging.

\section{Turbidity}

Experimental studies by Taneja and Khepar (1996) demonstrate that the hydraulic conductivity of the aquifer in the vicinity of the well decrease during recharge presumably by the movement of suspended solids and associated minor aquifer clogging. So the injected water should have low suspended solids. The efficiency of graded sand filter and well filter in removing suspended solids from the source pond water in all the sites are shown in Fig. 4. 


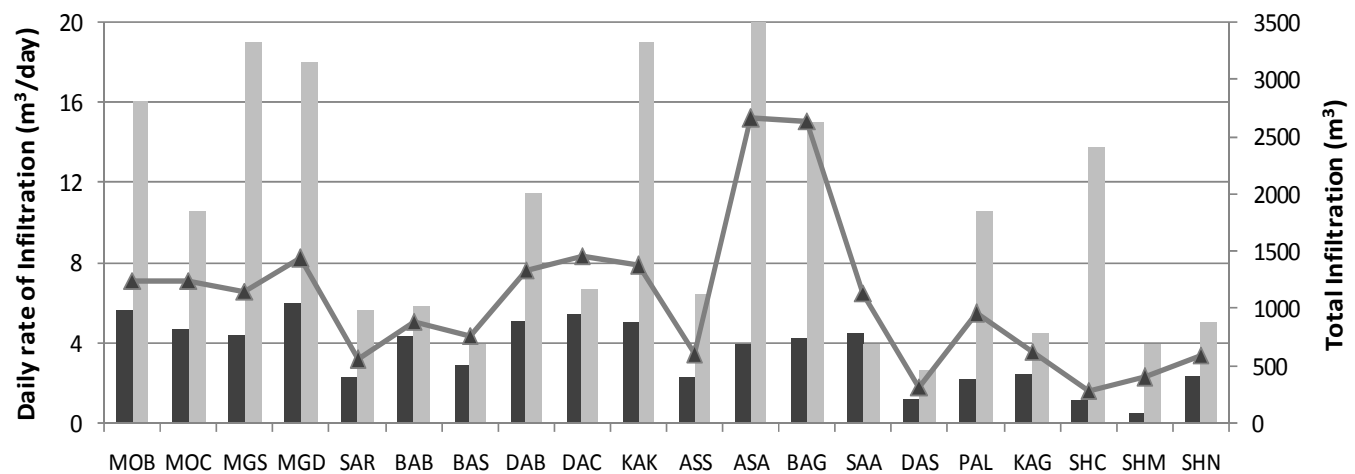

Mean operational Infiltration rate $\quad$ Optimum infiltration rate from falling head test $\_$Total Infiltration_31.03.2013

Fig. 3. Comparison of mean operational rate and optimum rate of infiltration from falling head test in bar diagram with total amount of infiltration in line curve.

The turbidity of source (pond) water ranges from 50 to 150 NTU except at one site. Turbidity decreases to 5 NTU after passing through the sand filter at 12 sites; the same at other sites has reduced to $<60$ NTU except at KAG and SHN where the filter beds have been found to ineffective in removing turbidity and pose the high risk of well clogging. Turbidity of water from the abstraction wells ranges from 0 to 50 NTU in most wells. In some sites the turbidity of abstraction wells (MGS, SAA, SAR, MGD and SHM) are higher than filtered water and this may be due to the problem of well construction or presence of higher amount of DOC in the ambient groundwater.

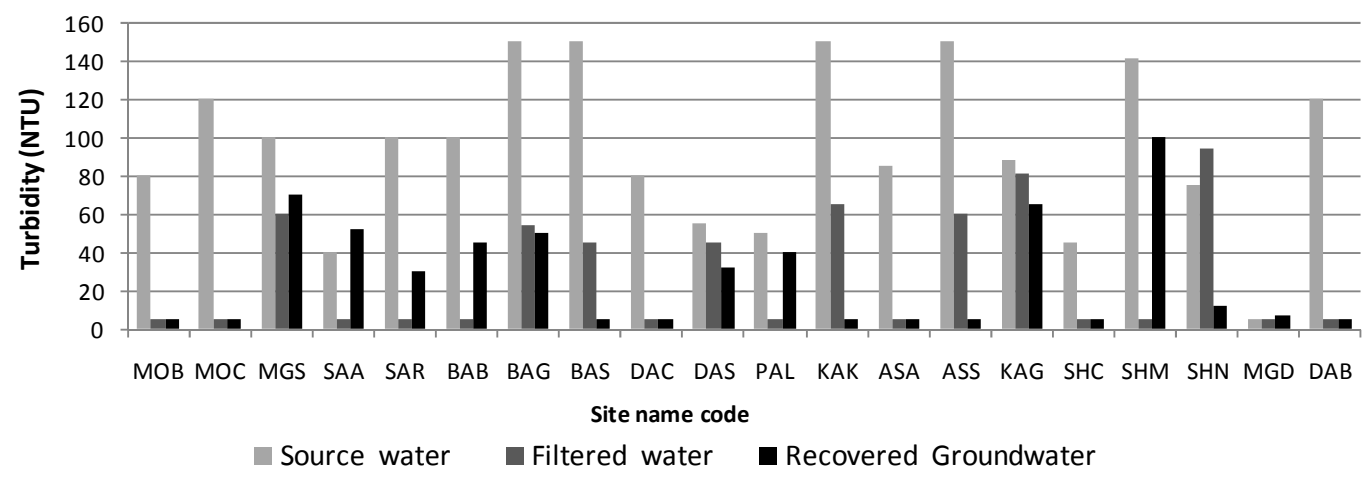

Fig. 4. Reduction in turbidity from source to filtered water and filtered water to recovered water (Data of 31 March, 2013). 


\section{Coliform bacteria counts}

Time series plot of total coliform counts of pond water, filtered water and recovered MAR HTW and reference HTW water at two sites Assasuni (ASA) and Batiaghata (BAG) are shown in Fig. 5 and it can be deciphered from the figure that the sand filter is efficient in reducing the coliform of source water.

\section{Natural aquifer treatment ( $3^{\text {rd }}$ stage of filtration)}

In most instances, injection and recovery from the same well is preferred for economic reasons as it is less expensive than construction of dedicated injection and recovery wells. However, using separate injection and recovery wells is desirable to improve stored waterquality by providing additional residence time and to take advantage of aquifer filtration in addition to operational perspective (Maliva et al. 2006) which has been achieved in the current research as a small diameter abstraction well has been placed in the centre of the large diameter infiltration wells. Operational and experimental results indicate that concentrations of some contaminants e.g., disinfection byproducts, nutrients, and microorganisms are decreases by natural inorganic and microbiological processes during storage (Pyne 2002, McQuarrie and Carlson 2003, Pavelic et al. 2005).
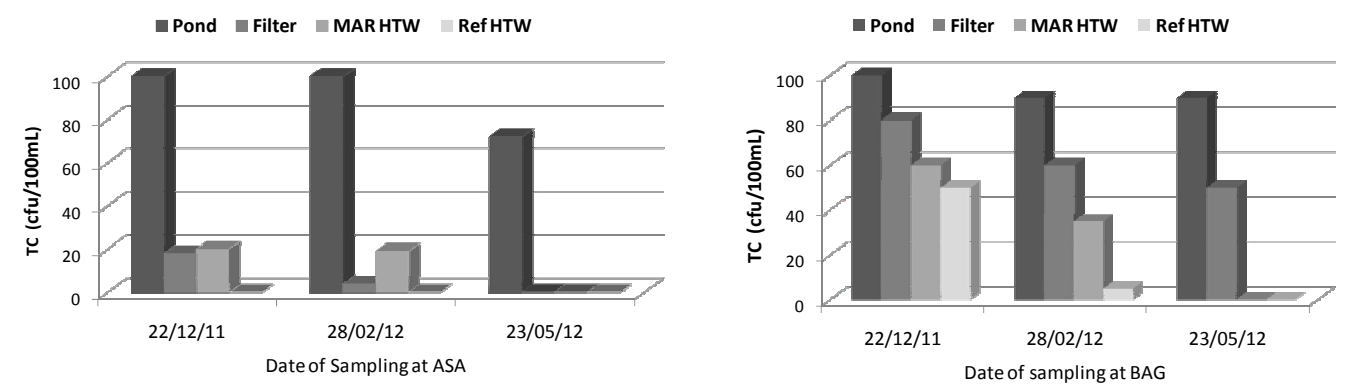

Fig. 5. Time series plot of total coliform counts of pond water, filtered water and MAR, HTW and reference HTW water at ASA (left) and BAG (right).

\section{Management of physical clogging}

The finer materials that accumulate on the top of the sand filter have been removed periodically. Also the top fine sand of the recharge well is replaced once a month to maintain good infiltration rate. In case of significant reduction of infiltration rate of a particular well, well purging has been carried out to improve the well performance. For wells using sand aquifers as storage zones, back flushing may be needed on a daily or weekly basis (Brown et al. 2006). Periodic back flushing is performed at the MAR schemes in the coastal area of Bangladesh using mechanical pumps connected to the deep monitoring well inside the aquifer at a much higher rate of pumping compared to 
injection rate. Clogging by air entrainment can occur if water is allowed to cascade into the well, and bubbles are produced that block pore space and restrict flow. Dissolved gases may also be released from solution due to temperature changes of source to groundwater. Preventing air entrainment during well injection is achieved by the monitoring wells inside the infiltration wells as they are placed below the static water level.

\section{Biological clogging}

Bacteria produce biofilms when nutrients (e.g., sulphur, nitrogen and phosphorus) present in the source water stimulate microbial activity. Nitrate $\left(\mathrm{NO}_{3}{ }^{-}\right)$concentration of pond water ranges from 1.5 to $131 \mathrm{mg} / \mathrm{l}$ whereas in ambient groundwater its concentration is from 1.1 to $61 \mathrm{mg} / \mathrm{l}$. Sulphate $\left(\mathrm{SO}_{4}{ }^{2-}\right)$ concentration of pond water recorded on 11/7/12 ranges from 4.5 - $330 \mathrm{mg} / \mathrm{l}$ in 20 sites but reduced to $4-113 \mathrm{mg} / \mathrm{l}$ on 15/9/12 may be due to the dilution with rainwater. Ambient groundwater was with high $\mathrm{SO}_{4}{ }^{2-}$ content which has been observed to be reduced after 2 months of infiltration (Fig. 6, right). Phosphate $\left(\mathrm{PO}_{4}{ }^{3-}\right)$ concentrations of pond water on both the dates are more or less similar and ranges from 0.02 to $1.5 \mathrm{mg} / \mathrm{l} . \mathrm{PO}_{4}{ }^{3-}$ content has also been observed to be reduced after 2 months of infiltration in almost all sites except MOC site (Fig. 6, left). This high nutrient content of the MAR sites in coastal area of Bangladesh pose the risk of biological clogging.
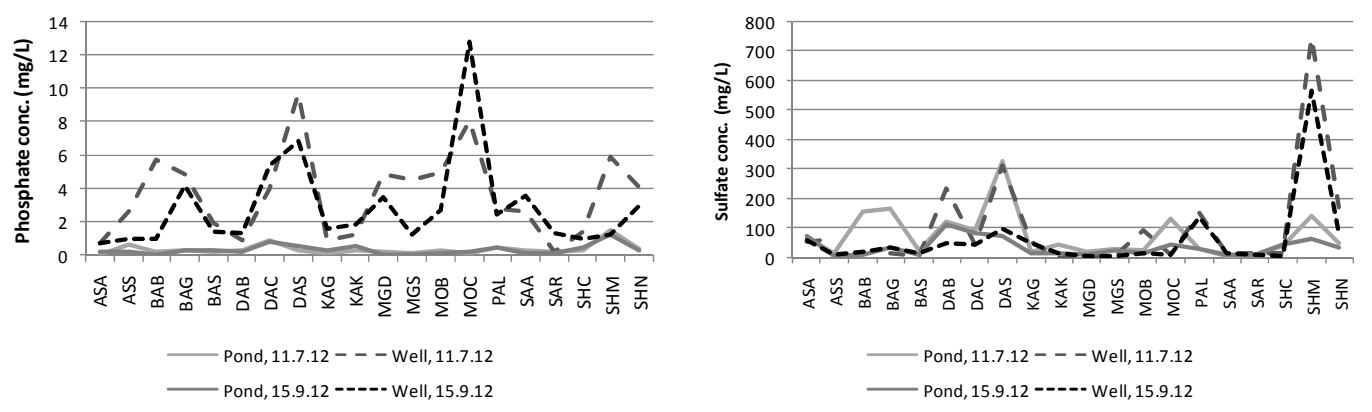

Fig. 6. Concentration of phosphate and sulfate in pond water (on 11/7/12 and 15/9/12), ambient groundwater on 11/7/12 (before infiltration) and mixed groundwater on 15/9/12 (after 2 months infiltration).

\section{Clay swelling and dispersion}

Two possible causes of reduction of permeability around the wells in the sandstone aquifers i.e. clay swelling and dispersion have been discussed by Brown and Silvey (1977). For a MAR system using a brackish water aquifer for a storage zone, clays may swell when freshwater is introduced by the exchange of cations (Maliva and Missimer 2010). The situation is similar to the current study and the aquifer is susceptible to this kind of clogging. Although the clays may subsequently contract when the freshwater is 
pumped out and original salinity conditions are restored (Maliva and Missimer 2010) but for this current study this positive impact can hardly be expected as the abstraction volume is very low compared to infiltration volume and a $100 \%$ recovery is not possible due to mixing of water. This tends to be most prevalent where reactive clays (montmorillonite) are present. However, XRD analysis of sediment samples from the wells need to be done to decipher the type of clay present in aquifer in different sites.

\section{Aquifer heterogeneity and fluid-rock interactions}

Aquifer heterogeneity and fluid-rock interactions can greatly impact MAR system performance. The overall clogging rate in heterogenous aquifers will be greater than that of homogenous aquifer (Maliva and Missimer 2010). Precipitation of iron oxides and hydroxides and calcium carbonate are the predominant form of geochemical clogging. Iron hydroxide precipitation may occur when water containing dissolved oxygen without dissolved ferrous iron $\left(\mathrm{Fe}^{2+}\right)$ is mixed with water containing $\mathrm{Fe}^{2+}$ and no dissolved oxygen (Moorman et al. 2002). This is a very common scenario because the water injected in most MAR systems contains high dissolved oxygen and most deep aquifers

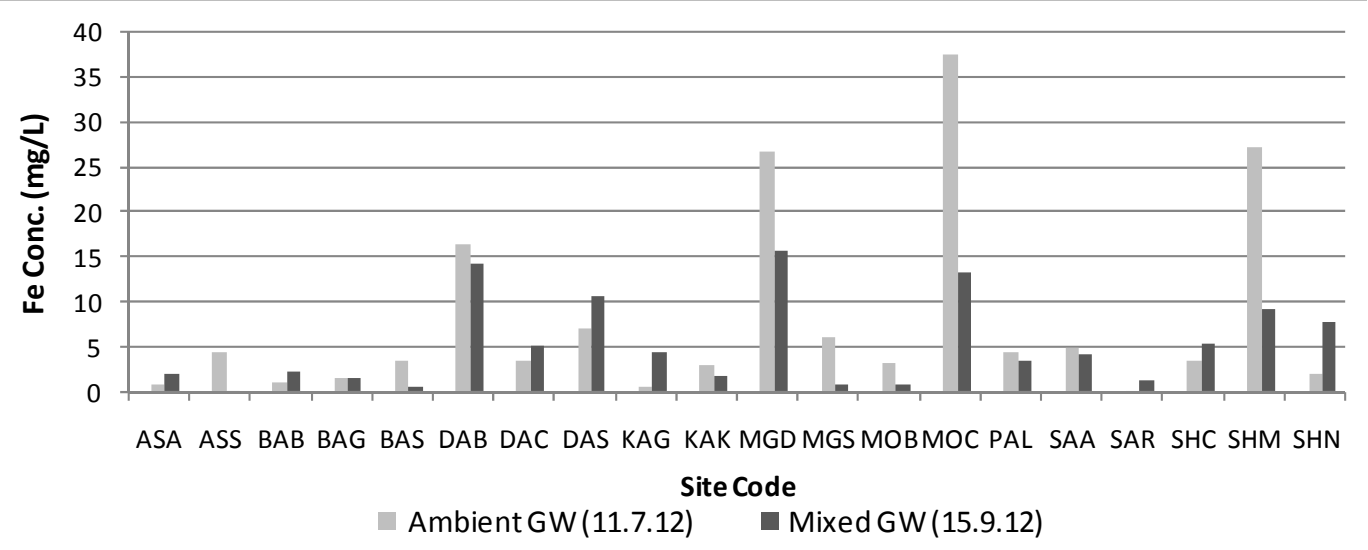

Fig. 7. Concentration of iron of ambient groundwater on 11/7/12 (before infiltration) and mixed groundwater on 15/9/12 (after 2 months infiltration).

are chemically reducing (Maliva and Missimer 2010). DO content of pond water is high and ranges from 6.5 to $7.5 \mathrm{mg} / \mathrm{l}$ (Harun and Kabir 2012). The aquifer in the coastal plain of Bangladesh contains iron rich minerals and high levels of soluble iron are found to be present in ambient groundwater. This soluble iron in the presence of dissolved oxygen, and nitrate stimulate bacteria such as Gallionella and Leptothrix to produce precipitates that cause clogging (Dillon and Pavelic 1996). Moreover as the source water is slightly alkaline ( $\mathrm{pH} 8.3$ to 8.5 ), it can be considered to stabilize iron sulfides by forming a protective ferric hydroxide coating on the iron bearing mineral surfaces which is again 
pose the risk of clogging. The majority of minerals that precipitate in wells are the result of biological activity which may either create local chemical microenvironment that have thermodynamic conditions favorable for mineral precipitation or act as catalyst for precipitation. In this study the concentration of iron of ambient ground water was higher which has been reported to be reduced significantly after 2 months of injection period (Fig. 7). Though the reduction of iron in recovered water indicate improved water quality but it again pose the risk to chemical clogging.

The Sodium adsorption ratio (SAR) is a good indicator of the tendency of infiltrating water to reduce permeability (Tchobanoglous and Schroeder 1987). SAR is determined for all the sites using the equation,

$$
S A R=\frac{N a^{+}}{\sqrt{\left(C a^{+}+M g^{2+}\right)}}
$$
where, all values in

meq/L and plotted in bar diagram for visual comparison among pond water, ambient groundwater and mixed water after 2 months of injection (Fig. 8). SAR of pond water is very low compared to ambient groundwater. After 2 months of injection, SAR has been found to reduce significantly in almost all sites except two (KAG and SHC) where it has been seen to increase. So, except these two sites there is very little chance of permeability reduction whereas the risk of clogging can be anticipated in KAG and SHC sites.

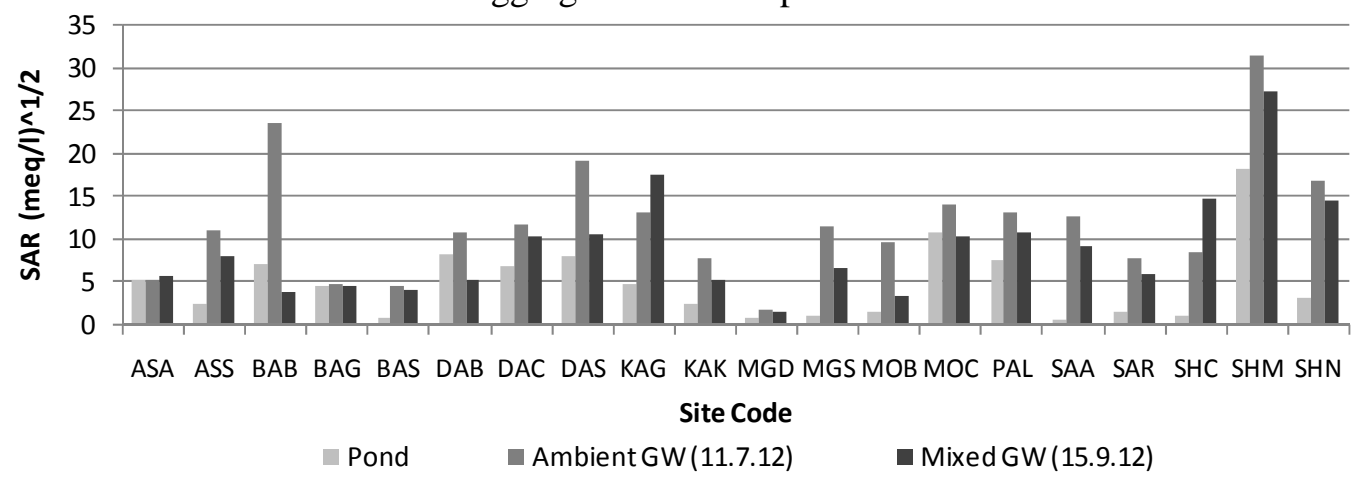

Fig. 8. Sodium adsorption ratio (SAR) in pond water, ambient groundwater (11.7.12) and mixed groundwater (15.9.12).

\section{Conclusion}

After filtration, storage of rooftop rain water and pond water improved quality with turbidity decreasing from 150 to $<60$ to $>5$ NTU and coliform bacteria counts decreasing from 100 to less than $50(\mathrm{cfu}) / 100 \mathrm{ml}$. As filtration system cannot remove the coliform completely, disinfection must be adopted after filtration where the impact of disinfectant byproduct should be considered as they could lead significant clogging. A maximum infiltration rate of $6 \mathrm{~m}^{3} /$ day has been achieved at a number of sites where the average is about $3 \mathrm{~m}^{3} /$ day. After three years of operation very small deterioration in infiltration rate 
has been observed in the oldest sites. Relatively high nutrient content present both in source water and groundwater could cause biological clogging. Probability of clogging due to clay swelling should be considered due to salinity difference of source water and groundwater although SAR has been observed to be reduced which reduce the risk of reduction of permeability. There is possibility of chemical plugging in the aquifer and around the well from the precipitation of iron bearing minerals as dissolved iron concentration in the groundwater has been observed to be reduced. Though MAR scheme is focused mostly on water supply aspect, there are various scientific aspects need to be assessed in detail for ensuring the long term sustainability of the scheme. Column test, batch experiment, core sample analysis, XRD analysis of sediment sample is highly recommended to get a broader view of clogging.

\section{References}

Brown, C. J., Hatfield, K. and Newman, M. 2006. Lessons learned from a review of 50 ASR projects from the United States, England, Australia, India and Africa. Proceedings 2006 Universities council on water resources/The National Institute of Water Resources Annual Conference. p. 11.

Brown, D.L. and Silvey, W. D. 1973. Underground storage and retrieval of freshwater from a brackish water aquifer. In: Braunstein, J (ed.), Underground waste management and artificial recharge: Proceedings, 2nd International Symposium, New Orleans, September, 1973: U. S. Geological Survey (available from the Groundwater Protection Council Library). pp. 379-419.

Dillon, P. and Pavelic, P. 1996. Guidelines on the quality of storm water and treated wastewater for injection into aquifer for storage and reuse: Urban Water Resource Association of Australian Research Report No. 109. p. 48.

Harun, M. A. Y. A. and Kabir, G. M. M. 2012. Evaluating pond sand filter as sustainable drinking water supplier in the southwest coastal region of Bangladesh, Appl. Water. Sci., DOI 10.1007/s13201-012-0069-7.

Maliva, R.G. Guo, W. and Missimer, T.M. 2006. Aquifer storage and recovery: Recent hydrogeological advances and system performance. Water Environ. Res. 78:2428-2435.

Maliva, R.G. and Missimer, T.M. 2008. Aquifer storage and recovery and the development of sustainable water supplies, missimer groundwater science, a Schlumberger company, American water works association, sustainable water sources.

Maliva, R.G. and Missimer, T.M. 2010. Aquifer storage and recovery and managed aquifer recharge using wells: Planning, hydrogeology, design and operation, Schlumberger water services, Methods in Water Resources Evaluation, Series No. 2.

McQuarrie, J.P. and Carlson, K. 2003. Secondary benefits of aquifer storage and recovery: Disinfection by-product control. J. Environ. Engin. 129:412-418.

Okubo, T. and Matsumoto, J. 1983. Biological clogging of sand and changes in organic constituents during artificial recharge. Water Res. 17(7): 813-821 
Pavelic, P. Nicholson, B.C. Dillon, P.J. and Barry, K.E. 2005. Fate of disinfection by-products in groundwater aquifer storage and recovery with reclaimed water. J. Contaminant Hydro. 77:351-373.

Pyne, R.D.G. 2002. Aquifer storage recovery wells: The path ahead. Florida Water Resources J. 2:19-27.

Taneja, D.S. and Khepar, S.D. 1996. Effect of artificial groundwater-recharge on aquifer parameters using cavity well: Groundwater 34:335-340

Tchobanoglous, G. and Schroeder, E. D. 1987. Water quality: Characteristcs, modeling and modification. Addison-Wesley, Menlo Park, California. p. 786.

(Manuscript received on 18 May, 2014; revised on 29 May, 2014) 